Aleksandar Cuculić, Ph.D.

E-mail: cuculic@pfri.hr

Jasmin Ćelić, Ph.D.

E-mail: jcelic@pfri.hr,

Rene Prenc, Ph.D.

E-mail: prenc@pfri.hr

University of Rijeka, Faculty of Maritime Studies, Studentska 2, 51000 Rijeka, Croatia

\title{
Marine Diesel-generator Model for Voltage and Frequency Variation Analysis During Fault Scenarios
}

\begin{abstract}
Various faults in ship's electrical power system, primarily those connected with diesel-generators, governors and automatic voltage regulators, may lead to oscillations in generator load, voltage and frequency. If those transients are large enough, a partial or total blackout may occur. In order to prevent such events, it is very important to get an insight into dynamic behaviour of electrical energy sources on board vessel. In this paper, a dynamic model in the time domain of marine diesel-generator is presented. The model is realized in the MATLAB/SIMULINK environment and consists of three main parts: the synchronous generator model, diesel-engine governor model and voltage regulator model. Simulation of a sudden loss of one generator when two generators are running in parallel is performed. Simulation results show that the presented model is fully applicable for the purpose of analysis of the marine diesel-generator dynamic behaviour during transient periods.
\end{abstract}

Key words: Diesel-generator, ship's electrical system, diesel-engine governor, voltage regulator, time domain simulation

\section{Introduction}

Brushless self-excited synchronous generators driven by a medium speed diesel engine are the primary electrical power sources on board modern vessels. Stability of electrical power supply depends on many factors related to their proper operation but voltage and frequency are the most important ones. Stable power supply system is the one in which energy sources are returning to their original state after having been exposed to disturbances, or periodically accept a new steady state without any loss of 
synchronism. In other words, voltage and frequency should stabilize within the time interval specified by class society regulations.

Disturbances in the system, which generally occur due to dynamic phenomena related to faults and sudden load changes, cause the oscillatory swinging of the rotor and the load due to effects of the resulting torques that accelerate or break the rotor. These transients cause changes in the generator load angle, and consequently in voltage and frequency. If the specified torques are large enough, the loss of synchronism in the generator may occur, which will most certainly lead to total or partial blackout in the system.

Diesel-generator dynamic response to sudden load changes is a result of the combined interaction of all the system components. It is impossible to quantify all influential factors which determine the dynamic response of diesel-generators. The most important factors usually considered in practice are:

- diesel-engine governor response,

- type of generator,

- type and characteristics of excitation system,

- voltage regulator response,

- diesel-generator torque characteristics,

- diesel-generator moment of inertia.

One of the worst case scenarios that may occur in ship's power network is sudden loss of one or more generators running in parallel, which will cause instantaneous load increase on remaining generators [1][2]. It is very important, both for vessel's electrical system designers and operators, to be familiar with the diesel-generator response during such events.

Very often, it is not possible or may even be dangerous to test all possible failure scenarios on board vessel. For that reason, a dynamic model of diesel-generator which includes all the above mentioned influential factors is developed. The main purpose of the model is simulation of the diesel-generator voltage and frequency dynamic response during sudden load changes.

\section{Synchronous generator model}

Modelling the dynamic behaviour of synchronous generator is quite complex because of the rotor winding movement relative to the three phase armature windings, so the magnetic coupling coefficient changes continuously with the rotor position. Such model of synchronous machine can be described by differential equations with timevarying values of mutual inductances, the solution to which is not always easy to find.

In order to build a synchronous generator model that is independent of timevarying terms, and therefore suitable for computer simulation, it is necessary to express the rotor and stator variables in separate coordinate systems. Mathematical model of 
synchronous generator is based on Park's transformation. Voltage equations of imaginary armature circuits in the direct (d) and quadrature (q) axis are obtained by the linear transformation of voltage equations in three phase abc into dq coordinates [3][4].
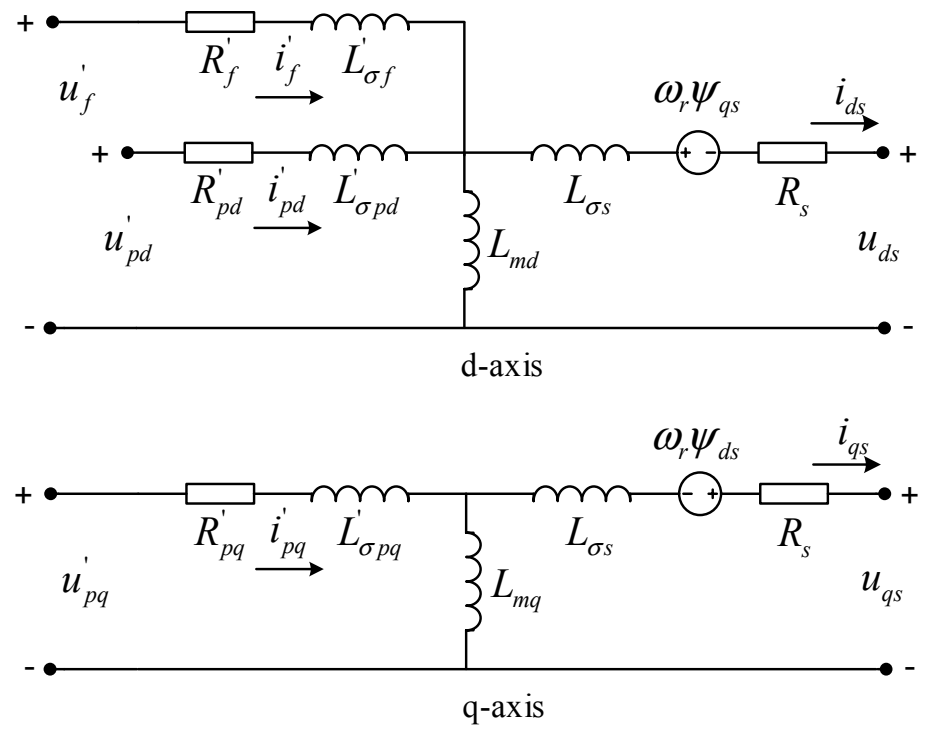

Figure 1. Synchronous generator equivalent circuit in dq coordinate system

All electrical variables and parameters in the dq equivalent circuit of synchronous generator (Fig. 1) are mapped to the stator side [5] and are defined as follows: $u_{d s}$ and $u_{q s}$ are the stator (armature) winding voltages in d and q axes, $R_{s}$ stator winding resistance, $L_{\sigma s}$ stator leakage inductance, $u_{f}^{\prime}$ voltage at field winding terminals, $i_{f}^{\prime}$ field winding current, $L_{\text {of }}^{\prime}$ field winding leakage inductance, $R_{f}^{\prime}$ field winding resistance, $u_{p d}^{\prime}$ and $u_{p d}^{\prime}$ damper winding voltages of the $\mathrm{d}$ and $\mathrm{q}$ axes, $i_{p d}^{\prime}$ and $i_{p d}^{\prime} u_{p d}^{\prime}$ damper winding currents of the $\mathrm{d}$ and q axes, $L_{\text {бpd }}^{\prime}$ and $L_{\text {opq }}^{\prime} u_{p d}^{\prime}$ damper winding leakage inductances of the $\mathrm{d}$ and $\mathrm{q}$ axes, $R_{p d}^{\prime}$ an $R_{p q}^{\prime}$ damper winding resistances of the $\mathrm{d}$ and $\mathrm{q}$ axes and $L_{m d}$ and $L_{m q}$ main mutual inductances of the $\mathrm{d}$ and q axes.

The synchronous generator is modelled as a fifth order system. It is assumed that voltages at the generator terminals are equal and balanced and only the fundamental harmonic is present in the air gap field (impact of high order harmonics is ignored). The model is based on the following voltage equations in dq axes [5][6][7]:

$$
\begin{aligned}
& u_{d s}=-R_{s} i_{d s}+\frac{d \psi_{d s}}{d t}-\omega_{r} \psi_{q s} \\
& u_{q s}=-R_{s} i_{q s}+\frac{d \psi_{q s}}{d t}+\omega_{r} \psi_{d s}
\end{aligned}
$$




$$
\begin{gathered}
u_{f}^{\prime}=R_{f}^{\prime} i_{f}^{\prime}+\frac{d \psi_{f}^{\prime}}{d t} \\
u_{p d}^{\prime}=R_{p d}^{\prime} i_{p d}^{\prime}+\frac{d \psi_{p d}^{\prime}}{d t} \\
u_{p q}^{\prime}=R_{p q}^{\prime} i_{p q}^{\prime}+\frac{d \psi_{p q}^{\prime}}{d t}
\end{gathered}
$$

$\psi_{d s}$ and $\psi_{q s}$ are the stator flux linkages of the $\mathrm{d}$ and q axes, $\psi_{f_{f}}^{\prime}$ field winding flux linkage and $\psi^{\prime}{ }_{p d}$ and $d \psi_{p q}^{\prime}$ damper windings flux linkages of the $\mathrm{d}$ and $\mathrm{q}$ axes.

Eqs. (1) to (5) are expressed in terms of currents and flux linkages. Since the currents and flux linkages are mutually dependent, both cannot be independent state variables. In order to find a transfer function suitable for simulation model, it is necessary to express the voltages in a term of single variable. In this particular case the flux linkages are chosen. For synchronous generator with one field winding in $\mathrm{d}$ axis and one pair of damper windings in $\mathrm{d}$ and $\mathrm{q}$ axes, the following equations can be used [6]:

$$
\begin{gathered}
\psi_{d s}=\int\left(u_{d s}+\frac{R_{s}}{L_{m d}}\left(\psi_{m d}-\psi_{d s}\right)+\omega_{r} \psi_{q s}\right) d t \\
\psi_{q s}=\int\left(u_{q s}+\frac{R_{s}}{L_{m q}}\left(\psi_{m q}-\psi_{q s}\right)-\omega_{r} \psi_{d s}\right) d t \\
\psi_{f}^{\prime}=\int\left(u_{f}^{\prime}+\frac{R_{f}^{\prime}}{L_{\sigma f}^{\prime}}\left(\psi_{m d}-\psi_{f}^{\prime}\right)\right) d t \\
\psi_{p d}^{\prime}=\int u_{p d}^{\prime}+\frac{R_{p d}^{\prime}}{L_{\sigma p d}^{\prime}}\left(\psi_{m d}-\psi_{p d}^{\prime}\right) d t \\
\psi_{p q}^{\prime}=\int \frac{R_{p d}^{\prime}}{L_{\sigma p q}^{\prime}}\left(\psi_{m d}-\psi^{\prime}{ }_{p d}\right) d t
\end{gathered}
$$

The main mutual inductances of the $\mathrm{d}$ and $\mathrm{q}$ axes $\psi_{m d}$ and $\psi_{m q}$ are:

$$
\begin{gathered}
\psi_{m d}=L_{m d}\left(i_{d s}+i_{p d}{ }_{p d}+i_{f}{ }_{f}\right) \\
\psi_{m q}=L_{m d}\left(i_{q s}+i^{\prime}{ }_{p q}\right)
\end{gathered}
$$

From Eqs. (6) to (12) currents through generator windings can be calculated as follows:

$$
i_{d s}=\frac{\psi_{d s}-\psi_{m d}}{L_{\sigma s}}
$$




$$
\begin{gathered}
i_{q s}=\frac{\psi_{q s}-\psi_{m q}}{L_{\sigma s}} \\
i_{f}^{\prime}=\frac{\psi_{f}^{\prime}-\psi_{m d}}{L_{\sigma f}^{\prime}} \\
i_{p d}^{\prime}=\frac{\psi_{p d}^{\prime}-\psi_{m d}}{L_{\sigma p d}^{\prime}} \\
i_{p q}^{\prime}=\frac{\psi_{p q}^{\prime}-\psi_{m d}}{L_{\sigma p q}^{\prime}}
\end{gathered}
$$

Diesel-generator is a rotating system consisting of the diesel motor prime mover and a synchronous generator connected via the common shaft. The equation of the motion describing the system is:

$$
\frac{2}{P} \frac{d \omega_{r}(t)}{d t}=T_{m}-T_{e m}-T_{d a m p}
$$

where $\omega_{r}$ is the rotor angular velocity in rad/s, $J$ moment of inertia in $\mathrm{kgm}^{2}, T_{m}$ mechanical shaft torque in $\mathrm{Nm}, T_{e m}$ electromagnetic torque in $\mathrm{Nm}, T_{\text {damp }}$ damping torque in Nm and $P$ is the generator power in $\mathrm{W}$. 

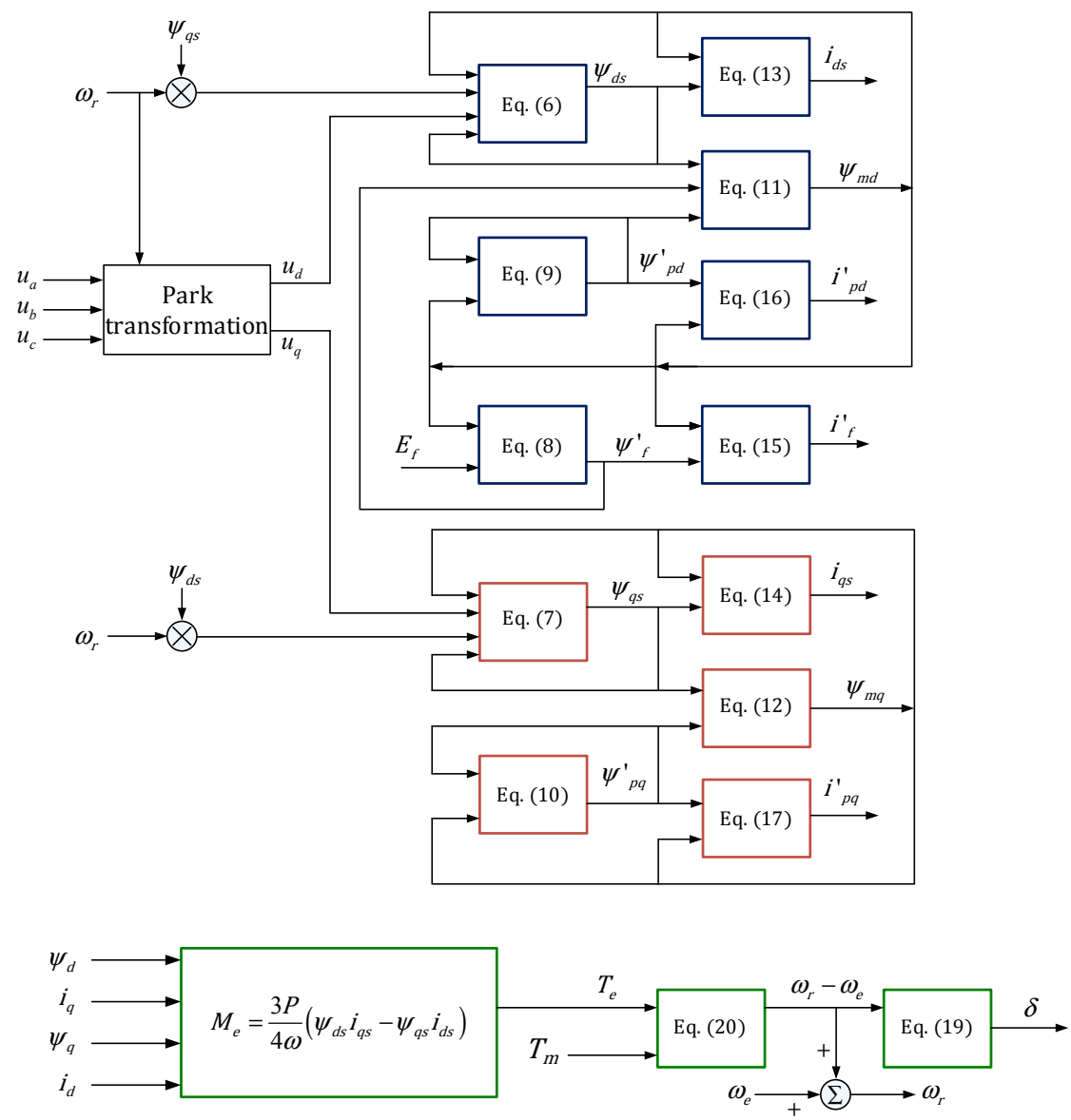

Figure 2. Block diagram of a synchronous generator model

The load angle $\delta$ in radians can be expressed as:

$$
\delta(t)=\theta_{r}(t)-\theta_{e}(t)=\int_{0}^{t}\left(\omega_{r}(t)-\omega_{e}\right) d t+\theta_{r}(0)-\theta_{e}(0)
$$

where $\theta_{r}(t)$ is the angle between the rotor q axis and stationary axis of the stator reference phase winding in radians, $\theta_{e}(t)$ angle between the synchronously rotating reference frame $\mathrm{q}$ axis and the stationary axis of the stator reference phase winding in radians, and $\omega_{e}$ electrical angular velocity in $\mathrm{rad} / \mathrm{s}[6]$.

Since the network frequency, and thus the electrical angular velocity of ship's diesel generator must be constant, it follows that $\frac{d\left(\omega_{r}(t)-\omega_{e}\right)}{d t}=\frac{d \omega_{r}(t)}{d t}$. 
Eq. (18) can be rewritten as:

$$
\omega_{r}(t)-\omega_{e}=\frac{P}{2 J} \int_{0}^{t}\left(T_{m}-T_{e m}-T_{\text {damp }}\right) d t
$$

Block diagram of the synchronous generator model is shown in Fig. 2. Equations (1) to (17) are the base for electrical part and equations (18) to (20) for mechanical part of the model.

\section{Diesel-engine governor model}

Block diagram of the diesel engine governor model is shown in Figure 3 [8][9]. The generator actual speed $\omega_{r}$ is compared with the reference speed $\omega_{\text {ref }}$. Error signal is applied to the input of controller, which is modelled as a second order system:

$$
H_{c}(s)=\frac{K_{p}\left(1+T_{3 c} s\right)}{1+T_{1 c} s+T_{1 c} T_{2 c} s^{2}}
$$

where $K_{p}$ is the gain and $T_{1 c}, T_{2 c}, T_{3 c}$ the controller time constants.

The actuator transfer function is:

$$
H_{a}=\frac{1+T_{1 a} s}{s\left(1+T_{2 a} s\right)\left(1+T_{3 a} s\right)}
$$

where $T_{1 a}, T_{2 a}, T_{3 a}$, and are the actuator time constants.

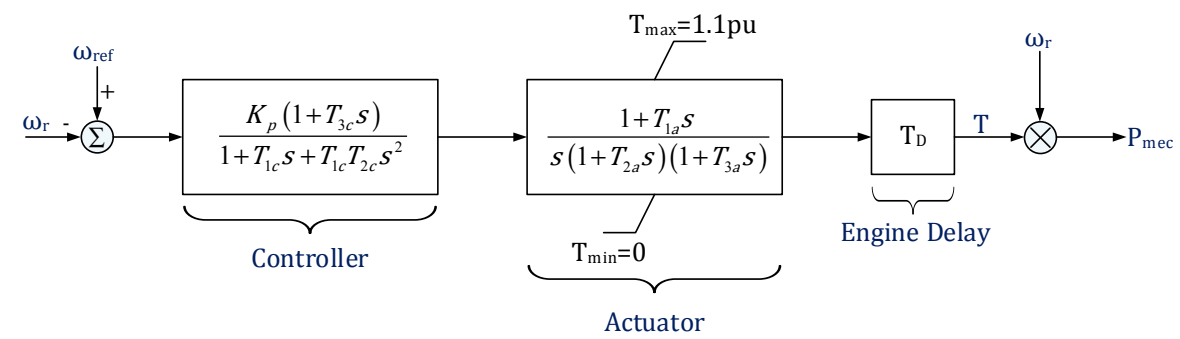

Figure 3. Block diagram of the diesel-engine governor model

The output of the actuator block is the prime mover mechanical torque command which is limited to $110 \%$ of the nominal power according to class society rules [lit]. The mechanical torque command is sent to the engine delay block with delay time $T_{D}$ and is multiplied by the rotor angular speed $\omega_{r}$. The result is the mechanical power signal $P_{\text {mec }}$ which is used as an input for the mechanical part of the synchronous generator model. 


\section{Voltage regulator model}

The voltage regulator model is based on the IEEE recommended practice for excitation system models for power stability studies. The base of the model is the IEE AC5A brushless excitation system where the regulator is supplied from a permanent magnet generator, which is the most common arrangement for marine generators [10]. Block diagram of the voltage regulator model is shown in Fig 4.

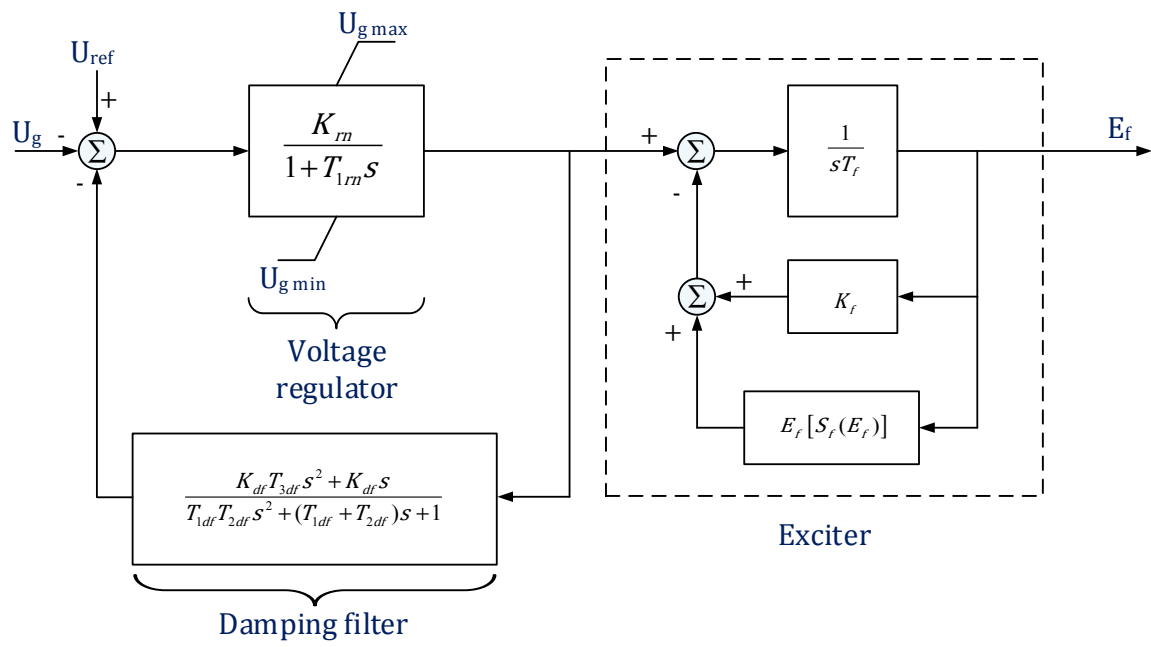

Figure 4. Block diagram of the voltage regulator model

Reference value of the generator output voltage $U_{\text {ref. }}$ is compared with its actual value $U_{g}$ which is obtained from the output of the electrical part of the synchronous generator model. Error signal is applied to the input of the voltage regulator with the following transfer function:

$$
H_{v r}=\frac{K_{v r}}{1+T_{1 v r} s}
$$

$K_{v r}$ is the voltage regulator gain and $T_{1 v r}$ its time constant.

In order to prevent oscillations in the generator output voltage, a damping filter is used in the regular feedback line. The damping filter transfer function is:

$$
H_{f}(s)=\frac{K_{d f} T_{3 d f} s^{2}+K_{d f} s}{T_{1 d f} T_{2 d f} s^{2}+\left(T_{1 d f}+T_{2 d f}\right) s+1}
$$

Where $K_{d f}$ is the gain, and $T_{1 d f}, T_{2 d f}, T_{3 d f}$ are the damping filter time constants. 
The exciter is modelled as a PI regulator with the gain $K_{u}$ and time constant $T_{u}$. The output of the exciter is the generator field voltage $E_{f}$, which is applied to the corresponding input of the synchronous generator model. The exciter saturation function $S_{f}\left(\mathrm{E}_{f}\right)$ represents the demands for the field voltage increase due to the effects of saturation, and can be satisfactorily defined by two values of field voltage $E_{f 1}$ and $E_{f 2}$. The procedure for determining the saturation function can be found in [10] [11].

\section{Simulation results}

Diesel-generator simulation model parameters are shown in Table 1. Parameter values are obtained from [12].

Table 1. Diesel-generator simulation model parameters

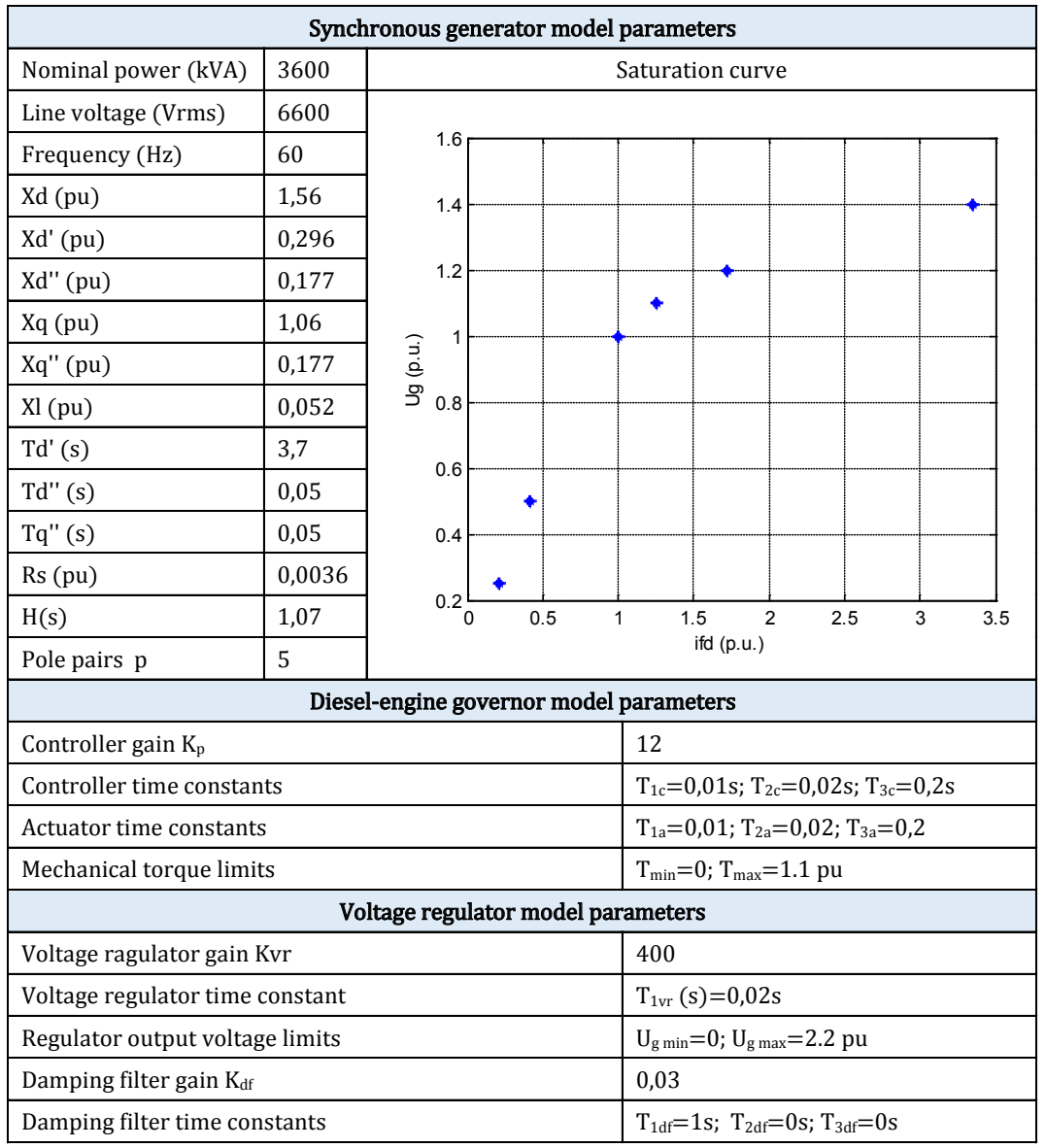


The model is realized in Simulink using the standard block from the SimPowersystem library. Generator parameters that are normally available in generator data sheets, and are also used in this model, are: synchronous reactance in $\mathrm{d}$ and $\mathrm{q}$ axes $\mathrm{Xd}$ and $\mathrm{Xq}$, generator leakage reactance $\mathrm{Xl}$, transient reactance $\mathrm{Xd}$ ', sub transient reactance in $\mathrm{d}$ and q axes Xd", and Xq", stator resistance Rs, transient short-circuit time constant Td' and sub transient short-circuit time constants Td" and Tq". The equations connecting the above mentioned parameters with parameters used in Eqs. (1) to (17) can be found in [5][6][7].

The following scenarios are simulated:

1. Two generators are running in parallel, each loaded with approximately $55 \%$ of the nominal load and one generator is suddenly disconnected from network.

2. Two generators are running in parallel, each loaded with approximately $85 \%$ of the nominal load and one generator is suddenly disconnected from network.

Electrical protections used in the simulation model are set as follows:

- The under frequency and over frequency protection disconnects the generator circuit breaker if frequency drops under $90 \%$ or rise above $110 \%$ of the nominal frequency, with time delay of 5 seconds.

- Under voltage protection disconnects the generator circuit breaker if voltage drops below $70 \%$ of its nominal value, with time delay of 2 seconds.

With respect to simulated scenarios, the effect of the turbocharger lag is ignored and is assumed that diesel-engine is able to take a 55\% rated load in one step.

Simulation results for the first scenario are shown in Figure 5. At $\mathrm{t}=3 \mathrm{~s}$ generator number 2 is suddenly disconnected from the network and generator number 1 is instantly taking over the entire load. The frequency drop undershoot equals $6 \%$, and the voltage drop undershoot $9 \%$ of the nominal value. Both, the voltage and frequency are stabilized after the transient period of 4.8 seconds, while the voltage is stabilized within $\pm 3 \%$ of its nominal value in 1.2 seconds, which is accordance with class requirements.

Voltage and frequency do not exceed the limits set by corresponding electrical protections, and they maintain their nominal values after the transient period. Generator number one is loaded with $110 \%$ of its nominal power (which is the maximum allowable load for marine generators). In this case, there is no need for fast load reduction, but no further increase of power consumption is possible until a stand-by generator is connected to the network.

In Figure 6, simulation results for the second case are shown. In $\mathrm{t}=3 \mathrm{~s}$, generator number 2 is suddenly disconnected from the network, causing a step load increase on the remaining generator. The value of $85 \%$ of the nominal load is chosen because the specific fuel consumption in $\mathrm{g} / \mathrm{KWh}$ of modern medium speed diesel engines gets close to its minimum value near this load point. 
The maximum voltage undershoot is $13.5 \%$ of its nominal value. Although the voltage value is all the time above the limits set by the under voltage protection, it still fails to stabilize at $\pm 3 \%$ of its nominal value within the period of 1.5 seconds after the start of the transient. Frequency continuously drops and at $\mathrm{t}=10.66 \mathrm{~s}$ the under frequency protection disconnects the generator circuit breaker and a blackout occurs. It is clear that in this case a proper fast load reduction method is required to prevent blackout.
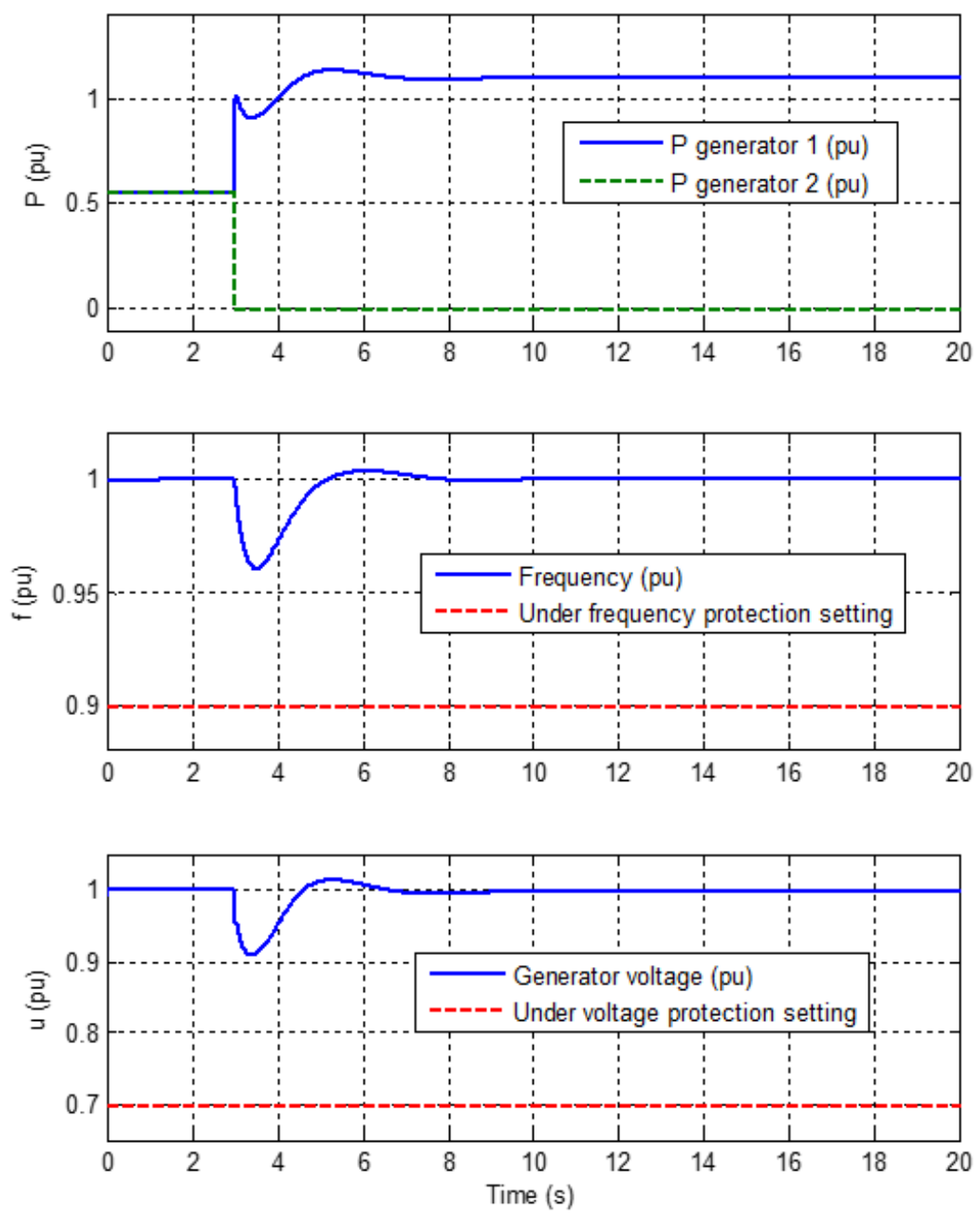

Figure 5. Simulation results for one generator failure when two generators are running in parallel with 55\% of the nominal load 

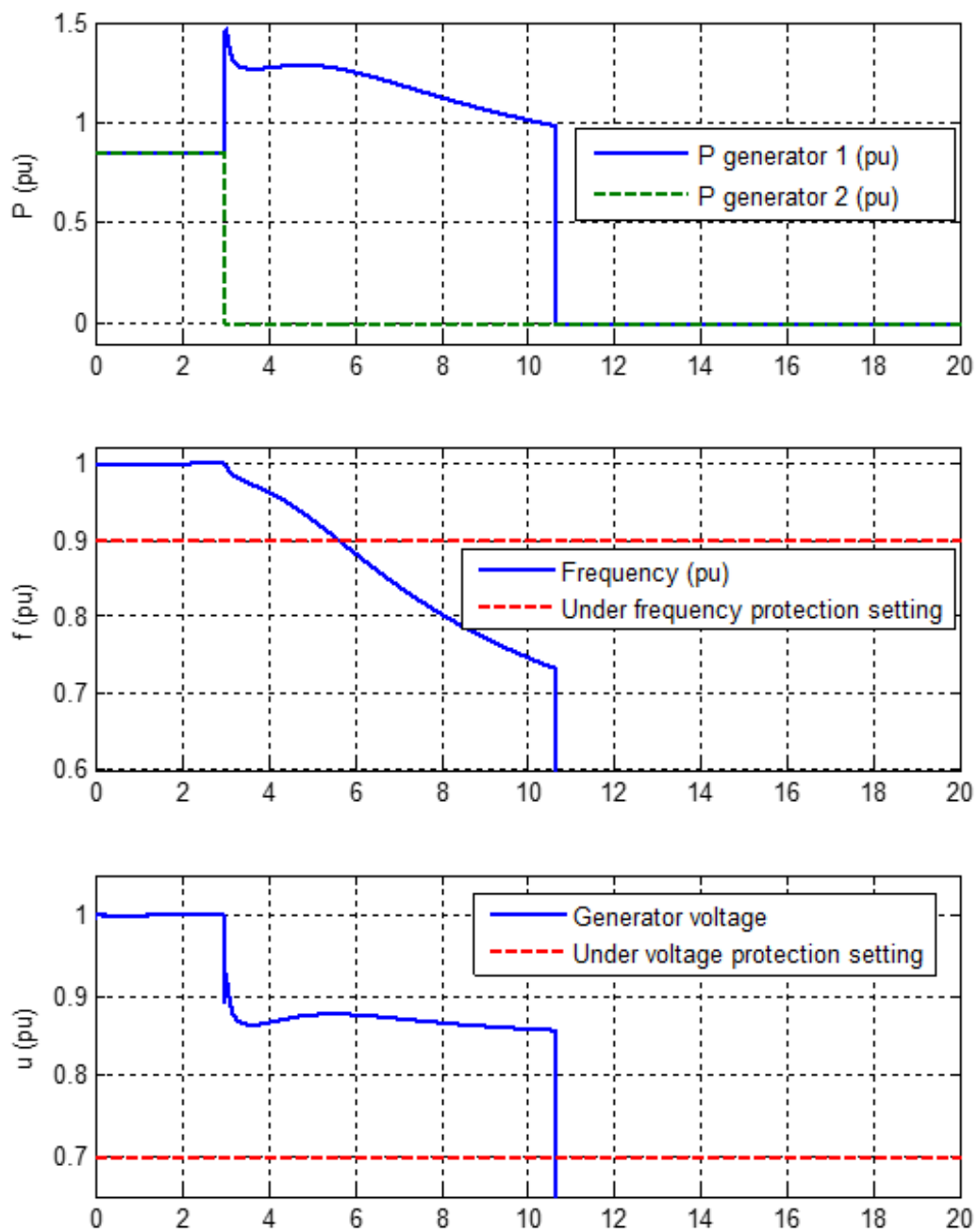

Figure 6. Simulation results for one generator failure when two generators are running in parallel with $85 \%$ of the nominal load

\section{Conclusion}

In this paper, a dynamic model of the marine diesel generator is presented. Its main purpose is simulation of a diesel-generator dynamic behaviour during various fault scenarios. The focus has been put on frequency and voltage variations. The model consists of three separate parts (synchronous generator model, diesel-engine governor 
model and voltage regulator model) and is realized using the Matlab/Simulink software. Its modular structure allows it to be easy adapted to various system configurations. Also, it is not limited to single generator operation and can be used for the simulation of two or more diesel-generators behaviour when running in parallel. Diesel-generator parameters used in the presented model are chosen in a way making them easily obtainable from manufacturer's data sheets.

Simulation has been performed for the worst case scenarios when two generators are running in parallel and one of the generators is suddenly disconnected from network. In the first case, the load on each generator was $55 \%$ and in the second case $85 \%$ of its nominal power. Simulation results show that the presented model is fully applicable for the analysis of different fault scenarios. Beside the analysis of voltage and frequency variations during the transient period, it can also be used for simulation and analysis of the generator protection circuits operation.

\section{Literature}

1. Wilkes, D.E., Power Management and Blackout Prevention, Dynamic Positioning Conference, Huston, US., 2001.

2. Lauvdal, T., Ådnanes, A.K., 2000, Power Management System with Fast Acting Load Reduction for DP Vessels, Dynamic Positioning Conference, Huston, US.

3. Krause, P.C., Analysis of Electric Machinery.: McGraw-Hill, 1986.

4. Kundur, P., Power System Stability and Control.: McGraw-Hill, 1994.

5. Žarko, D., Dinamički model sinkronog stroja. Available online: https://www.fer.unizg.hr/ download/repository/TESIT_2014_2015_Dinamika_sinkroni.pdf

6. Ong, C., Dynamic Simulation of Electric Machinery.: Prentice Hall PTR, 1998.

7. Bulić, N., Upravljanje sustavom uzbude sinkronog generatora upotrebom neuronske mreže, Magistarski rad, 2005.

8. Luo, L., Gao, L., Fu, H., "The Control and Modelling of Diesel Generator Set in Electric Propulsion Ship," International Journal of Information Technology and Computer Science (IJITCS), vol. 3, no. 2, pp. 31-37, 2011.

9. Murty, M.S.R., Diesel enegine governor model. Available at: http://www.sarienergy.org/PageFiles/ What_We_Do/activities/CEB_Power_Systems_Simulation_Training,_Colombo,_Sri_Lanka/ Course_ppts/Lecture_29_Modeling_Diesel_Engine_Gov_Sys.pdf.

10. IEEE Power Engineering Society, IEEE Recommended Practice for Excitation System Models for Power System Stability Studies, 2005.

11. Mathworks, AC5A Excitation system, Available at: http://www.mathworks.com/help/physmod/ sps/powersys/ref/ac5aexcitationsystem.html

12. AVK generatos manual. Available at: https://www.scribd.com/doc/250349130/AVR-Cosimat-N 
Aleksandar Cuculić, Jasmin Ćelić, Rene Prenc

\section{Model brodskog dizelskog generatora za analizu odziva frekvencije i napona u uvjetima kvara}

\section{Sažetak}

Razni poremećaji unutar brodskog elektroenergetskog sustava, a posebno kvarovi povezani s dizelskim generatorima, regulatorima broja okretaja i automatskim regulatorima napona mogu dovesti do oscilatornog njihanja rotora i opterećenja te posljedično napona i frekvencije generatora. Ukoliko su dovoljno velike, navedene oscilacije mogu dovesti do djelomičnog ili potpunog ispada elektroenergetskog sustava. U cilju sprječavanja takvih pojava vrlo je važno dobiti uvid u dinamičko ponašanje izvora električne energije na brodu. U ovom radu predstavljen je dinamički model brodskog elektroenergetskog sustava u vremenskoj domeni. Model se sastoji od tri dijela: modela sinkronog generatora, modela regulatora broja okretaja i modela regulatora napona. Provedena je simulacija iznenadnog ispada jednog generatora kad dva generatora rade u paraleli. Rezultati simulacije pokazuju da je predstavljeni model u potpunosti primjenjiv za analizu dinamičkog ponašanja brodskih dizelskih generatora kod naglih promjena opterećenja.

Ključne riječi: dizelski generator, brodski elektroenergetski sustav, regulator broja okretaja, regulator napona, simulacija u vremenskoj domeni 